\title{
On a Romantic Island: Shakespeare and Mamma mia
}

\begin{abstract}
The paper concerns the blockbuster musical film Mamma mia, loosely using some of Shakespearean patterns, topoi and plots. Set on a small Greek island, idylic and exotic, the film offers a contemporary romantic story with new/reversed roles in terms of gender, parenthood, sexuality, marriage and age, pointing to a different cultural paradigm. While the Shakespearean level is recast, remixed and probably less visible, the priority is given to the utopia of the 1970 s and to the question of its outcome and transformation.
\end{abstract}

Keywords: Mamma mia, musical, popular culture, Shakespeare, The Tempest.

This paper concerns the blockbuster musical film Mamma mia (2008) which loosely uses some of Shakespearean patterns, topoi and plots. Set on a small Greek island, idyllic and exotic, the film offers a contemporary romantic story with reversed or reconsidered roles in terms of gender, parenthood, sexuality, marriage and age, pointing to a different cultural paradigm. The musical romantic comedy film Mamma mia is based on the stage musical (1999) with songs of the 1970s popular music group ABBA:

The young Sophie, living with her single mother on a Greek island, is about to get married. She wishes her father would give her away though she never knew who it was. In her mother's diary she had found out that there were three men in question. Despite that she never saw them for they all live far away; she invites all three of them to her wedding without telling her mother Donna. Also, Donna's two girl-friends occur-decades earlier they were known as a girls' music band (singing ABBA songs). After an array of comic situations and unexpected appearances, before the wedding ceremony, all of the three men proclaim themselves Sophie's fathers. There is a wedding at the end-yet not Sophie, but her mother Donna is to be wed to one of the "fathers." Sophie, instead, prefers not to get married yet for she wants to explore the world firstshe and her fiancé sail away.

Academy of Performing Arts Bratislava, SK. 
The pattern sounds Shakespearean, indeed: there are lovers or potential family members separated by the sea over many years; there is an exotic island serving as asylum for a single parent family; there is a crossing of the sea from far away to reveal the unknown; there is a young couple just about to marry; there are three competing suitors and three unwed women; there are mistaken, unknown identities; there are sub-plots mirroring the main story; there are many joyful comic situations; and there is a dance party similar to a masque, mixing up and confusing the identities up to the point of dizziness. And a happy reunion and a wedding at the end. Many of the pattern, topoi and plots bring to mind The Tempest. And yet, in Mamma mia, most of the topoi are reversed and rewritten, referring to a different social and cultural paradigm compared to the one of Shakespeare's time. The following essay will point out the reversals concerned with parenthood and gender, sexuality, marriage and age.

\section{Single Mother}

In Shakespeare's plays, mothers are marginalized and often absent; if mentioned at all, they are passive, rather objects or instrumentalized in terms of reproduction, representing wombs giving birth; often they are denied a voice or completely absent (Rose 292-294; Hyland 140; Lenker 43; Kahn 95; Orgel 99-112; Adelman 10). Mothers, definitely, have never an active position and are never at the centre of the play. In The Tempest, all of the three mothers (of Miranda, Caliban and Ferdinand) are physically absent.

In Mamma mia, the centre of the story turns on Donna, Sophie's mother. A single mother (!). In Shakespeare's days, single mothers were socially outcast, stigmatized and legally deprived (Cressy 74-75; Mitterauer 38, 42). There is only one single mother in the whole Shakespeare canon: Sycorax in The Tempest. And Sycorax, significantly, is absent from the play. She is referred to as "the foul witch" (1:2:259) practicing "mischiefs manifold and sorceries terrible" (1:2:265); and she bore a monster "got by the devil himself” (1:2:321). Hence Sycorax embodies all the prejudices the society had towards single mothers - this is why she, her offspring and her potential partner, too, are cast negative.

In Mamma mia, Donna is not only a single mother withholding the identity of the child's father: in the incriminated time some twenty years ago, she had an affair with three men. In Shakespeare's time, women were not allowed sexual autonomy, mainly because it would undermine the patrilinearity and legitimity of their children (Stone The Crisis 662-664; Stone The Family 501-503). Female promiscuity, when lead to motherhood, was castigated. Illegitimate children were called bastards; they were legally deprived and cast negative, if not described as monsters (Cressy 74-75). Shakespeare, too, was 
conform with this notion: both his characters of illegitimate sons-Caliban (The Tempest) and Edmund (King Lear) — are cast negative; and Perdita (The Winter's Tale), daughter of Hermione who was accused by her husband for adultery, has been abandoned in the wilderness. In Measure for Measure, premarital sexual relationship that had led to pregnancy is criminalized: Claudio, who made Juliet pregnant before they got married, is sentenced to death, and she is presented as a victim. In Titus Andronicus, Tamora's illegitimate new born child is called "shame and [...] disgrace" (4:2:60) and even its mother orders to “christen it with [...] dagger's point” (4:2:70). ${ }^{1}$

Yet in Mamma mia, Donna-dressed in blue like a madonna-is not cast negative at all, neither her daughter Sophie. The opposite is true: Donna is a radiant single mother; self-determined though slightly stressed, too; yet able to manage her life and to bring up her daughter without a man around; and supposedly free to live her sexuality upon her choice. The latter achievement, however, was rejected by her parents' generation and put to the proof: when Donna became pregnant, her mother disowned her. In the film, this fact is mentioned rather as a footnote, not of heavy relevance, yet it refers to the perusing clash of generations in the 1970s as far as the voluntary single parenthood was concerned. Donna is played by Meryl Streep, the ultimate Hollywood star and, at the same time, a rare scandal-free celebrity. Besides her girlish appearance and professional mastery, it might be worth considering that with Donna, cast by an other actress with a weaker moral reputation, the story would probably not work that iconically.

\section{Fatherhood-Motherhood-Daughterhood}

In Shakespeare's plays, fathers, contrary to rather absent or silenced mothers, are dominant and the chief source of identity for their children (Stone The Family 154ff; Stone The Crisis 592ff; Kahn 95-98). The father's role is to endow authority: even if obeying it is at stake, even when children oppose or deny it (as they often do), even if fathers are wrong or already dead, the paternal authority is a steady topos and a point of reference. As many social and cultural studies have shown, through the early modern period, with successive establishing of the nuclear family as the dominant social model, the father was given the uppermost moral and spiritual authority (Stone Family 151-217; Williamson 146; Orgel 108). The pyramidal patriarchal power structure, with the father at the top, has been derived both from nature and from the Bible and enhanced by numerous Protestant scriptures. The theologically justified authority of the father

1 Supposedly, mainly because it is dark-skinned; this fact further complicates the extramarital affair in the play. 
within the family has been projected onto the political hierarchy-with King James I being the "natural father of his subjects" (King James I qtd. in Williamson, 117) and "parens patriae" (King James I qtd. in Stone The Family 152). Shakespeare, too, conformed to this notion. As proof per negationem, I have noted elsewhere (Bžochová-Wild Začarovaný 77-82) that none of his most vicious characters (Richard III, Iago, Claudius, Macbeth, Angelo, Edmund, Antonio) is cast as father; ${ }^{2}$ thus, the paternal authority remains untouchable.

Prospero in The Tempest is not only a dominant father and almighty ruler of the island which provided him refuge after he had been exiled from home, but he turns out a politically powerful person, too, being the legal Duke of Milan; hence his daughter Miranda is supposed to mirror his identity of grandeur. While Prospero, the father, controls and possesses the island completely, including the life of his daughter; in Mamma mia, there is no explicit ruler nor proprietor of the island. Donna, the single mother, achieved a kind of economical independency and built up a decent life in close communion with nature and local rural people. Though the arrival of the three men in question triggers the plot, their importance for the daughter's identity is marginal - their fatherhood is never cleared and, at the end, each of the three men is happy to father at least "a third of her" (Mamma mia). Thus, the notion of patriarchal authority is completely abandoned, if not even mocked.

Obviously, Donna is not a female Prospera. The gender recast and update involved many other transpositions. Donna was not deposed from former authority; she does not control, neither manipulate the world by magic or howsoever; she did not subjugate the inhabitants; she does not patronize her daughter. Her life on the island is presented as harmonious, neither conquering nor possessive, as it is the case of Prospero. Her house and hotel Villa Donna is sunny and full of colours, though this romantic idyll is indulgently mocked by its technical imperfection (the building is on the brink of breakdown). Her exile seems rather deliberate than forced: Donna has no feelings of regret or bitterness being on the island itself; however, she does have this feeling, having been left by her lover once-which is a point to be discussed later. As far as the cultural topography is concerned, the remote green island is a perfect healthy place to live (yet opposed to Shakespeare: there is no such place as a desert island); the continental megapolises London and New York, where two of the three men come from, seem not to match up with the ideal of full personal happiness.

In Mamma mia, there is a strong mother-daughter bond, yet with a spark of rebellion on the part of the very young adult daughter. Sophie is far more active than Shakespeare's obedient and dependent Miranda: it is Sophie who

2 Except for Aaron in the early play Titus Andronicus. Aaron, who is of African origin, an "irreligious Moor," in act 4 becomes father of the illegitimate black baby delivered by Tamora. 
summons the three men from the past to come to the island in the hope to resolve the secret of the fatherhood. However, the purpose is purely formal: to fulfil the wedding ritual whereby the father traditionally "gives the daughter away"; not more. Thus, in Mamma mia, the father is not supposed to appear as a source of identity.

The intimate mother-daughter bond culminates with the song "Slipping through my fingers." Mourning the passing of time where the mother of a young adult discerns the "odd melancholy feeling" (Anderson and Ulvaeus, line 19) by relentlessly losing her child since its very first own steps to school may appeal quite moving for today's western audience for it captures the largely close relationship between children and parents and the emotional difficulty to launch them into independency. Neither such scenes nor emotions of parents towards their growing up off-springs are to be found in Shakespeare. The reason for this, as I have argued elsewhere (Bžochová-Wild 68-96), is his construction of families which mostly followed the older social pattern; and even if The Tempest could be understood as a transitive play shifting towards the closed domesticated nuclear family based upon "affective individualism," as Lawrence Stone put it (The Family 221-269), Prospero, the ruling almighty father is mourning rather his loss of "charms" (Epilogue: 1) than the loss of his daughter.

In Shakespeare's The Tempest, as in patriarchal societies, daughters (Miranda and Claribel) are transferred from father's hands to husband's as their possessions and have no autonomy (Stone The Family 271; Carlson 100; Jardine 115-116). In Mamma mia, however, the daughter makes the choices on her own, be it to decide on her future husband, on the right time to marry, or to question her origin. The most striking shift is Sophie's final decision not to marry yet and to explore the world instead: she and her fiancé sail away. This journey echoes the traditional Grand tour, known from the Renaissance and later, assigned for young wealthy men before they marry (Stone The Family 518; Locke $\$ 212$ to 215; Rousseau 1738-1893). Young daughters, as opposed to young sons, were advised to stay at home and grow up in security and isolation (Stone The Crisis 683).

Significantly, as Pierre Bourdieu (25) showed, the Grand tour features the archaic pattern of rite de passage, accompanying the separation of the boy from his mother and his initiation into male adulthood. In The Tempest, too, it is the young male Ferdinand, not the young female Miranda, to undergo such a journey before getting betrothed. In Mamma mia, however, there is a substantial gender reversal, for it is Sophie who decides to cross the sea and-as a consequence-to separate herself from her mother to achieve adulthood. The female ambition to see and to explore the world before entering into marriage is definitely at odds with Shakespeare's The Tempest, as well as with the practice of his time. 


\section{Husbands and Wives}

Concerning husband and wife, we remember from The Taming of the Shrew: "Thy husband is thy lord, thy life, thy keeper, / Thy head, thy sovereign" (5:2:151-152). Prospero, although his wife is absent, is a sovereign of exactly that kind, which he shows in relation to his daughter, too. In Mamma mia, Donna, the single mother of a twenty-year-old daughter, claims that she does not need a husband. Eventually, she marries her old love, Sam. But who is Sam? The film does not go at great length to explain their previous attachment. Judged by the cast, Sam (Pierce Brosnan, the legendary multiple James Bond and at that time the "sexiest man alive"3) seems to be the epitome of masculinity and coolness; but is he really? First, we see him as a well-off architect in New York, who, as it comes to light later, nevertheless failed in building up a decent relationship (he is divorced). Then, on the island, he seems rather helpless, far from a superman or a cool professional. Instead, the supposed 007 is the most embarrassing suitor; singing the ABBA love song "SOS" in duet with Donna, he appears magnificently awkward and clumsy. The actor obviously cannot sing well; neither is he comfortable in the role of a suffering lover.

So, what does this cast suggest? Is it that behind the beloved man there is a superman, however awkward he may actually appear? Or is it the oppositeshowing that any 007-look is just a plain facade? The film ingeniously pleases both these expectations. Sam in Mamma mia supposedly is James Bond, but at the same time he is not. Or should we read Donna's true love as a kind of parody of the Shakespearean three caskets choice? For there is an ironical note towards the self-determined woman Donna, who, having had her affairs with three men, ultimately loves that one who is a kind of 007. Yet there is no doubt that he will neither be Donna's lord, nor her keeper or sovereign. And most probably neither a clever superman (the only occupation he gets involved in is helping Donna to decorate the terrace). On the green island, neither his remote New York professional career nor his (intertextual) reputation as super-agent has a value; the only thing that counts is his bond to Donna.

The island in Mamma mia functions as a locus of metamorphosis, of purging relationships, maturing decisions, coming to oneself. The other two potential fathers undergo a change, too, by revealing their inner self. The lone wolf Bill (Stellan Skarsgård), an adventurer enjoying his lifelong freedom, may give up his celibacy, challenged by Donna's old friend Rosie, the go-getter, yet notoriously single. Harry (Colin Firth), the banker, finally unburdens himself as gay. Neither fatherhood nor social career is given weight: again, it is the human bond that makes these men worthwhile. The traditional masculine role modelfather, governor, god — derived from patriarchy, is completely abandoned.

\footnotetext{
${ }^{3}$ The annual feature of the USA People magazine (2001).
} 
The three unwed women in their 40s or 50s, Donna and her two friends Rosie (Julie Walters) and Tanya (Christine Baranski), play out different selfdetermined models of life: a single parent mother (Donna), a happily multiple divorced (Tanya), a hyperactive intellectual single (Rosie). Obviously, they gained their gender autonomy during the feminist movement of the 1970swhile appearing on the stage as the music band "Donna and the Dynamos." Thus, Mamma mia may refer to a shift of social and cultural paradigm in terms of gender equality, be it marital or not.

\section{Age}

Though the happy ending of Mamma mia might look very much like a cliché, the marriage of Donna and Sam points to a shift of paradigm, too. In Shakespeare, as opposed to Mamma mia, fathers/parents of all young adults are rather old and belong, more or less, to the category of "senex"-known already from the classical antiquity: Prospero, Battista, Lear, Brabantio, Shylock, Polonius, Capulet, etc. Yet in Mamma mia, the eventual wedding unites singles of the parents' generation, not the young adults. Donna and Sam, a middle-aged couple, enter the institution of marriage-they do so definitely not because they are young (meaning capable to produce off-springs), as it is the standard topos in Shakespeare, as well as in his predecessors and contemporaries.

For the young adult Sophie, the marriage she was heading to proves to be too premature. As far as the middle adult woman, her mother, is concerned, the marriage is presented as a good option provided it is based upon mutual attachment and equality. In Shakespeare, we do not find a category of such vital middle adulthood. This, indeed, suggests a shift of paradigm. The parents in Shakespeare's plays use to step down from active life to clear the way for their children, ${ }^{4}$ which might suggest a standard social pattern of that time. As opposed to the early modern practice, from the end of the twentieth century, in close connection with increased life expectancy, the Western middle adulthood (roughly the age between 40 and 60) developed to a distinct category. However, it still remains probably "the least studied period of the lifespan" (Overstreet). As some suggest, in our time, the middle adult years "are probably the best time of life" and "the golden age of adulthood" (Colarusso 163) —a status which is not to be found in Shakespeare. On the contrary, Prospero, father of a 15-yearold daughter, is going to spend "every third thought" on his "grave" (5.1.314). This is surely not the case of Donna \& co. Thus, Mamma mia substantially

${ }^{4}$ Yet to be concerned: Gertrude, "the matron" heavily accused by her son Hamlet for her sexual relationship with Claudius: "...Rebellious hell, / If thou canst mutine in a matrons' bones" (3.4.82). As if the son would see her older than she feels herself. 
updates a Shakespearean story by introducing a new category of middle-age people, full of energy, joy and vitality and justifiable to marry or re-marry for love.

Significantly enough, the emphasis concerning the vitality of middle-age is laid on women. As far as the middle-aged men in Mamma mia are concerned, it is rather them who seem to undergo a midlife crisis with an urgent need to change their life. Yet these three male characters avoid the most common cliché, too, by being attached to women or a man of the same age. No doubt, a middleaged man falling in love with a young girl or boy would destroy the whole refreshing charm of the Mamma mia story and relapse to the all-too-traditional social pattern.

The notion of still vivid, even explosive sexual energy of middle adult women is reinforced by the seducing dance scenes on the hot midday sunny beach. Here, Tanya challenges the young barkeeper Pepper who "is only a child" (Mamma mia: "Does your mother know"). Since Pepper is played by an AngloAfrican actor (Philip Michael), the scene may recall the story of Shakespeare's Miranda sexually harassed by Caliban (1.2.349-353), the "other," who was often played by blacked up actors or by actors of African origin (Dymkowski 189; Vaughan and Vaughan 55; Griffith 197). Yet, in the film, the story is recast in terms of age and playfully distorted, stripped of any hint of violence, acknowledging the vital erotic appeal of both, a middle-aged woman and a young boy. Needless to say, the boy, as well as all the other young male dancers on the beach, eventually give up to Tanya's hot challenge and all of them faint at the end of the scene.

In Mamma mia, erotic energy is regarded as a vital positive power, no matter of which age. The sudden eruption of the Aphrodite's fountain immediately from beneath Donna's house-re-enacting a Shakespearean miracle and a celebration of love-adds an accomplishing romantic note to the happy end with a wedding. Yet important: the vivacity of middle adult women is praised not only at the end and not primarily in connection with men. In scene $3 / 10$, Tanya and Rosie prompt Donna, feeling blue and desperately grown up, to "grow back down again." Singing the song "Dancing queen," their energy of "young and seventeen" spreads like wildfire and infects dozens of women of all ages around to forget the daily routine and to join the dance and joy of life.

\section{0s and after}

To a great extent, the film's appeal is in its intertextual references. Besides the above-mentioned associations to the icon actors Meryl Streep and Pierce Brosnan, the film may especially address the middle-aged generation which grew up in the 1970s and 1980s with ABBA songs, bringing to their mind 
a whole range of reminiscences of that time. While the 1970s temporal level is only present as memory, the film, set in our time, i.e. about the turn of the millennium, presents rather the outcome of some of the 1970s narratives with the then young adults grown up to middle adulthood.

Those 1970s narratives informing Mamma mia concern mainly gender and environment: 1) the utopias of escaping the capitalism and returning to nature, epitomized in a green island (see Garforth); 2) the second wave of feminism with its struggle for sexual freedom; 3) the highest increase of nonmarital births (USA figures, see Doherty et al. page); 4) the emerging ideal of gender and marital equality statutory in the international bill of rights for women; ${ }^{5}$ ) the new anti-authoritarian parenting practices (see Walters and Walters page); 6) the gay liberation movement. With the 1970s behind them, the three mature women Donna, Rosie and Tanya seem to be better off, selfdetermined, self-made, still true to themselves and, yes, still sexy. The men, on the other hand, either grew out of the 1970s ideals to become upper-class pretentious establishment (Sam, Harry) or got stuck in a forever-young-dream (Bill). On a romantic island, they undergo a change.

\section{Conclusion}

The romantic musical comedy headed by three female producers (director Phyllida Lloyd, screenplay Catherine Johnson, production Judy Craymer) can be seen as a soft and slightly ironical feminist rewriting of Shakespeare's The Tempest. This paper's aim was to argue that the contemporary romantic story in Mamma mia is embedded in a changed cultural paradigm which was widely launched in the 1970s, and questions its outcome around the turn of the millennium.

\section{WORKS CITED}

Adelman, Janet. Suffocating Mothers. Fantasies of Maternal Origin in Shakespeare's Plays, Hamlet to Tempest. New York and London: Routledge, 1992.

Anderson, Benny G. B. and Bjoern K. Ulvaeus. "Slipping Through My Fingers." https:// www.azlyrics.com/lyrics/abba/slippingthroughmyfingers.html. 13 August 2019.

Bourdieu, Pierre. Masculine Domination. Trans. Richard Nice. Cambridge: Polity Press, 2001.

${ }^{5}$ The international bill of rights for women-The Convention on the Elimination of All Forms of Discrimination against Women (CEDAW) - was adopted in 1979 by the United Nations General Assembly and came into force in September, 1981. 
Bžochová-Wild, Jana. Začarovaný ostrov? Shakespearova Búrka inak. Bratislava: Divadelný ústav, 2003.

Carlson, Eric Josef. Marriage and the English Reformation. Oxford: Blackwell, 1994.

Colarusso, C. A. Child and Adult Development. New York: Springer Science + Business Media, 1992.

Cressy, David. Birth, Marriage and Death: Ritual, Religion, and the Life-Cycle in Tudor and Stuart England. Oxford: Oxford University Press, 1997.

Doherty, William J., Edward F. Kouneski, and Martha F. Erickson. "Responsible Fathering: An Overview and Conceptual Framework.” Journal of Marriage and Family. 60.2 (1998): 277-292. National Council on Family Relations. DOI: 10.2307/353848. https://www.jstor.org/stable/353848. 20 July 2019.

Dymkowski, Christine, ed. The Tempest. Shakespeare in Production Series. Cambridge: Cambridge University Press, 2000.

Garforth, Lisa. "Interview: Lisa Garforth on Green Utopias: Environmental Hope before and after Nature. Sociology Lens, 16 June 2018. https://www.sociologylens. net/article-types/opinion/interview-lisa-garforth-green-utopias-environmentalhope-nature/20893. 22 July 2019.

Griffth, David. "Caliban on the Stage.” William Shakespeare's The Tempest. A Casebook. Ed. D. J. Palmer. London: Macmillan 1991, rpt 1990. 184-200.

Hyland, Peter. An Introduction to Shakespeare. London: Macmillan, 1996.

Jardine, Lisa. Reading Shakespeare Historically. London: Routledge, 1996.

Kahn, Coppélia. "The Absent Mother in King Lear.” King Lear. Contemporary Critical Essays. London: Macmillan 1993. 92-109.

Lenker Tallent, Lagretta. Fathers and Daughters in Shakespeare and Shaw. Westport, Connecticut and London: Greenwood Press, 2001.

Locke, John, Some Thoughts concerning Education. (1693). Online Library of Liberty: A Collection of Scholarly Works about Individual Liberty and Free Markets. Arts and Humanities Research Council. Copyright 2004-2019. https://oll. libertyfund.org/titles/locke-the-works-vol-8-some-thoughts-concerning-educationposthumous-works-familiar-letters. 22 July 2019.

Mamma mia. Dir. Phyllida Lloyd. Film. Relativity Media, Littlestar Productions, Playtone, distr. Universal Pictures, 2008.

Mitterauer, Michael. Ledige Mütter. Zur Geschichte illegitimer Gebürten in Europa. München: Verlag C. H. Beck, 1983.

Orgel, Stephen. “Prospero's Wife.” William Shakespeare's The Tempest. Ed. Harold Bloom. New York: Chelsea House Publishers, 1988. 99-112.

Overstreet, Laura. "Lumen: Lifespan Development." Lumen Learning: Simple Book Production. Module 9: Middle Adulthood. "Introduction to Middle Adulthood." https://courses.lumenlearning.com/lifespandevelopment2/chapter/introductionto-lesson-9-middle-adulthood/. http://opencourselibrary.org/econ-201/. 22 July 2019.

People Magazine 2001. 22 July 2019. https://people.com/celebrity/the-sexiest-manalive-2001-pierce-brosnan/. 13 August 2019. 
Rose, Mary Beth. "Where Are the Mothers in Shakespeare? Options for Gender Representation in the English Renaissance.” Shakespeare Quarterly 42.3 (1991): 291-314.

Rousseau, Jean-Jacques. Emile, or Education. Trans. Barbara Foxley. London and Toronto: J. M. Dent and Sons, 1921; New York: E. P. Dutton, 1921. Online Library of Liberty: A Collection of Scholarly Works about Individual Liberty and Free Markets. Arts and Humanities Research Council. Copyright 20042019. https://oll.libertyfund.org/titles/2256\#Rousseau. 22 July 2019.

Shakespeare, William. The Complete Works. The Oxford Shakespeare. General editors Stanley Wells and Gary Taylor. $2^{\text {nd }}$ ed. 1997. Oxford: Oxford University Press, 1988.

Stone, Lawrence. The Crisis of the Aristocracy 1558-1641. Oxford: Clarendon Press, 1965.

. The Family, Sex and Marriage in England 1500-1800. London: Weidenfeld and Nicholson, 1977.

Vaughan, Alden T. and Virginia Mason Vaughan. Shakespeare's Caliban: A Cultural History. Cambridge: Cambridge University Press, 1991.

Walters, James and Linda Henley Walters. "Parent-Child Relationships: A Review, 1970-1979.” Journal of Marriage and Family 42.4 (1980): 807-822. Published by National Council on Family Relations. DOI: 10.2307/351826. https://www. jstor.org/stable/351826. 20 July 2019.

Williamson, Marilyn L. The Patriarchy of Shakespeare's Comedies. Detroit: Wayne State University Press, 1986. 